\title{
Geldanamycin, a Ligand of Heat Shock Protein 90, Inhibits the Replication of Herpes Simplex Virus Type 1 In Vitro
}

\author{
Yu-Huan Li, ${ }^{1}$ Pei-Zhen Tao, ${ }^{1 *}$ Yu-Zhen Liu, ${ }^{1}$ and Jian-Dong Jiang ${ }^{1,2 *}$ \\ Laboratory of Antiviral Research, Institute of Medicinal Biotechnology, Chinese Academy of Medical Sciences \\ and Peking Union Medical College, Beijing 100050, People's Republic of China, ${ }^{1}$ and Division of \\ Medical Oncology, Mount Sinai School of Medicine, New York, New York $10029^{2}$
}

Received 22 July 2003/Returned for modification 18 September 2003/Accepted 13 November 2003

\begin{abstract}
Geldanamycin (GA) is an antibiotic targeting the ADP/ATP binding site of heat shock protein 90 (Hsp90). In screening for anti-herpes simplex virus type 1 (HSV-1) candidates, we found GA active against HSV-1. HSV-1 replication in vitro was significantly inhibited by GA with an $50 \%$ inhibitory concentration of $0.093 \mu M$ and a concentration that inhibited cellular growth $50 \%$ in comparison with the results seen with untreated controls of $350 \mu \mathrm{M}$. The therapeutic index of GA was over 3,700 (comparable to the results seen with acyclovir). GA did not inhibit HSV-1 thymidine kinase. Cells infected with HSV-1 demonstrated cell cycle arrest at the $\mathrm{G}_{1} / \mathrm{S}$ transition; however, treatment with GA resulted in a cell cycle distribution pattern identical to that of untreated cells, indicating a restoration of cell growth in HSV-1-infected cells by GA treatment. Accordingly, HSV-1 DNA synthesis was suppressed in HSV-1 ${ }^{+}$cells treated with GA. The antiviral mechanism of GA appears to be associated with Hsp90 inactivation and cell cycle restoration, which indicates that GA exhibits broad-spectrum antiviral activity. Indeed, GA exhibited activities in vitro against other viruses, including severe acute respiratory syndrome coronavirus. Since GA inhibits HSV-1 through a cellular mechanism unique among HSV-1 agents, we consider it a new candidate agent for HSV-1.
\end{abstract}

Geldanamycin (GA) is a benzoquinone ansamycin and was first isolated as a new entity from the fermentation of Streptomyces hygroscopicus (3). GA binds with a high level of specificity within the ADP/ATP binding pocket of heat shock protein 90 (Hsp90) and inhibits the function of this chaperone (27, $36)$, resulting in inappropriately functioning and rapid degradation of Hsp90-associated client proteins $(2,28)$. The client proteins are mainly short-lived proteins, including several protein kinases (Raf-1, ErbB-2, and Bcr-Abl), p53, and pRb as well as cyclins and cyclin-dependent kinases $(2,25)$, which are degraded through the ubiquitin-proteasome pathway but protected by Hsp90 $(4,19)$. As a specific inhibitor of Hsp90 function, GA demonstrated antitumor activity in a multitude of animal models (23) and is now in clinical trial (phase I) in the United States (26). Interference with the function of Hsp90 seems to be the major mechanism of action of GA (29).

In a large-scale screening for novel candidates exhibiting activity against herpes simplex virus type 1 (HSV-1), we found (from the fermentation of S. hygroscopicus) a component active against HSV-1 replication. Chemical analysis of the purified compound showed a structure identical to that of GA. A study was then initiated to evaluate the potential of this compound in the treatment of HSV-1 infection. In the present study, the anti-HSV-1 effect of GA was examined in cell cultures. The possible molecular mechanism responsible for its activity against viral infection was also explored. Our investi-

\footnotetext{
* Corresponding author. Mailing address for Jian-Dong Jiang: Division of Medical Oncology, Mount Sinai School of Medicine, New York, N.Y. 10029. Phone. (212) 241-6441. Fax: (212) 996-9801. E-mail: jiandong.jiang@mssm.edu. Mailing address for Pei-Zhen Tao: Laboratory of Antiviral Research, Institute of Medicinal Biotechnology, Chinese Academy of Medical Sciences and Peking Union Medical College, 1\# Tian-Tan-Xi-Li, Beijing, 100050, P.R. China. Phone: 8610-63167255. Fax: 86-10-63017302. E-mail: pztao@public3.bta.net.cn.
}

gation showed that the mode of action of GA was closely related to the inactivation of cellular Hsp90 and different from that seen with the viral enzyme inhibitors (such as viral DNA polymerase or thymidine kinase [TK] inhibitors). We consider these results informative with respect to antiviral research.

\section{MATERIALS AND METHODS}

Compounds. GA was purchased from Sigma (St. Louis, Mo.). It was dissolved in dimethyl sulfoxide at $10 \mathrm{mg} / \mathrm{ml}$ as a stock solution and further diluted in the medium prior to use. Acyclovir was kindly provided by the Department of Chemical Drugs of the Chinese State Drug Administration (Beijing, China).

Cell, viruses, and plasmid. African green monkey kidney cells (Vero) were obtained from the Institute of Virology, Chinese Academy of Preventive Medicine (Beijing, China), and grown as specified in Eagle's minimum essential medium with $10 \%$ heat-inactivated fetal bovine serum plus antibiotics (penicillin, $250 \mathrm{U} / \mathrm{ml}$; streptomycin, $250 \mathrm{U} / \mathrm{ml}$ ). HSV-1 (SM44 strain) from the Institute of Virology, Chinese Academy of Preventive Medicine, was propagated in Vero cells. After three cycles of freezing and thawing and centrifugation $(1,800 \times g, 10$ $\min$ ), the supernatant containing the viruses as an infectious preparation was adjusted (on the basis of the PFU count) to hold equivalent amounts of virulence and kept at $-80^{\circ} \mathrm{C}$ until use. Plasmids prpTK and pTRI-GAPDH were gifts kindly provided by L. M. Schang, Department of Microbiology, University of Pennsylvania School of Medicine, Philadelphia. HSV-2 strain SAV, vesicular stomatitis virus (Indiana), human immunodeficiency virus type 1 (HIV-1) strain IIIB, coxsackie B3 virus (Cox B3) strain 3M, severe acute respiratory syndrome (SARS) coronavirus, and influenza viruses of types A (H3N2) and B (Jifan/13/97 isolate) were all from the Institute of Virology, Chinese Academy of Preventive Medicine. The SARS coronavirus was isolated in April of 2003 in Beijing from a hospitalized patient suffering from SARS.

Cytotoxicity determination. Vero cells in the exponential growth phase were seeded into 96-well microplates (Falcon, Oxnard, Calif.) at $2.5 \times 10^{4}$ cells per well followed by treatment with $\mathrm{GA}$ at $37^{\circ} \mathrm{C}$ for $72 \mathrm{~h}$ at concentrations between 0 and $1,000 \mu \mathrm{M}$ (in 10 steps). Cell viability was assessed by an MTT [3-(4,5dimethylthiazol-2,5-diphenyl tetrazolium bromide] assay (31). Cytotoxicity was determined in duplicate, and each experiment was repeated three times. The concentration that inhibited cellular growth $50 \%$ in comparison with the results seen with untreated controls $\left(\mathrm{CC}_{50}\right)$ was analyzed by nonlinear regression.

Anti-HSV-1 effect in vitro. Vero cell monolayers at about $85 \%$ confluence were infected with HSV-1 at a multiplicity of infection (MOI) of 0.1 PFU per cell. After $1 \mathrm{~h}$ of absorption at $37^{\circ} \mathrm{C}$, the cells were washed three times with phos- 
phate-buffered saline (PBS) and incubated at $37^{\circ} \mathrm{C}$ in the maintenance medium (Eagle's minimum essential medium plus 5\% fetal bovine serum) with or without GA. The viral titer of the samples (containing cells and the supernatant) was determined using a plaque assay (32) after a 1:10,000 dilution. The 50\% inhibitory concentration $\left(\mathrm{IC}_{50}\right)$ was defined as the concentration reducing plaque number by $50 \%$ compared to the results seen with untreated samples (which had a PFU in a range between 7.5 and 9.2 PFU per cell).

TK assay. The TK assay method was described previously (14). Briefly, GA at a final concentration between 0 and $50 \mu \mathrm{M}$ was mixed with HSV-1 TK (2 U/assay) in a 100- $\mu$ l reaction buffer containing $150 \mathrm{mM}$ Tris- $\mathrm{HCl}(\mathrm{pH} 7.5), 2 \mathrm{mM}$ ATP, $2 \mathrm{mM}$ $\mathrm{MgCl}_{2}, 3 \mathrm{mM}$ dithiothreitol, and $10 \mu \mathrm{M}$ methyl- $\left[{ }^{3} \mathrm{H}\right]$ thymidine and then incubated at $37^{\circ} \mathrm{C}$ for $30 \mathrm{~min}$. A $50-\mu \mathrm{l}$ sample was spotted onto a Whatman DE 81 paper circle followed by washing with $\mathrm{H}_{2} \mathrm{O}$ and ethanol. The dried circles were assessed (for radioactivity levels) in $10 \mathrm{ml}$ of BetaFluor (National Diagnostic, Atlanta, Ga.).

Effect of GA on viral adsorption. Cell suspensions were diluted in a precooled medium to a density of $4 \times 10^{6}$ cells per $\mathrm{ml}$ and incubated in melting ice for $2 \mathrm{~h}$. Precooled $\left(4^{\circ} \mathrm{C}\right) \mathrm{HSV}-1$ and GA were added to the cells with HSV-1 at a MOI of $1 \mathrm{PFU} / \mathrm{cell}$ and GA at concentrations between 0 and $20 \mu \mathrm{M}$. The mixture was incubated in ice for $1 \mathrm{~h}$ followed by three washing with ice-cold PBS. The cell pellet was diluted serially with cold PBS and added to new Vero cell monolayers, which were then covered with maintenance medium $-0.5 \%$ methylcellulose and incubated for plaque assay.

Measurement of viral penetration. The method for measurement of viral penetration was described before (7). Vero cell monolayers were placed on ice for $2 \mathrm{~h}$ followed by infection with HSV-1 (1 PFU/cell). After $1 \mathrm{~h}$ of adsorption at $4^{\circ} \mathrm{C}$, the free viruses were removed by washing with cold PBS followed by the addition of maintenance medium with or without GA. Viral penetration was initiated by shifting the incubation from 4 to $37^{\circ} \mathrm{C}$. Unpenetrated viruses were inactivated at each indicated time point by treatment with citrate buffer $(\mathrm{pH} 3.0)$ for $1 \mathrm{~min}$. The monolayers were then overlaid with maintenance medium and incubated for plaque assays.

Determination of viral release. Vero cell monolayers were exposed to HSV-1 at a MOI of $0.1 \mathrm{PFU}$ per cell for $1 \mathrm{~h}$, and then the monolayers were washed three times with PBS and grown in cultures with maintenance medium at $37^{\circ} \mathrm{C}$. After $30 \mathrm{~min}$ of incubation, the cells were treated with citrate buffer ( $\mathrm{pH} 3.0$ ) to inactivate the unpenetrated viruses and were incubated in maintenance medium with or without GA. The supernatant was collected $24 \mathrm{~h}$ later, and the monolayer was washed three times with PBS followed by the freezing and thawing process. Quantitative assay of the HSV-1 in the medium as well as in the cells was done separately by plaque assays after a 1:10,000 dilution of the samples.

Cell cycle analysis. Vero cell monolayers were infected with HSV-1 $(0.1$ $\mathrm{PFU} /$ cell) for $1 \mathrm{~h}$ followed by three washings in PBS. The cells were then grown in cultures at $37^{\circ} \mathrm{C}$ in the absence or presence of GA $(1 \mu \mathrm{M})$ and harvested $24 \mathrm{~h}$ later. Cell cycle distribution was measured using a Cycle TEST kit (Becton Dickinson, San Jose, Calif.). Levels of DNA luminescence of individual cells were examined with a FACScan flow cytometer and Cellfit software (Becton Dickinson).

Southern blot analysis. A total of $5 \times 10^{6}$ Vero cells were infected (using the protocol mentioned above) with HSV-1 at a MOI of $0.1 \mathrm{PFU} / \mathrm{cell}$. After washing, the cells were incubated in the maintenance medium with or without GA $(1 \mu \mathrm{M})$ for 12 and $24 \mathrm{~h}$. DNA was extracted from the cells with the reported method (12). Briefly, cells were lysed with $0.2 \mathrm{M}$ Tris- $\mathrm{HCl}(\mathrm{pH} 8.5)$ containing $100 \mathrm{mM}$ EDTA, $100 \mathrm{mM} \mathrm{NaCl}, 0.5 \% \mathrm{NP}-40,1 \%$ sodium dodecyl sulfate (SDS), and $100 \mu \mathrm{g}$ of protease $\mathrm{K} / \mathrm{ml}$. The resulting products were extracted with phenol and chloroform:isoamylalcohol $(24: 1[\mathrm{vol} / \mathrm{vol}])$ and precipitated with ethanol followed by centrifugation at 7,800 $\times g$ (Sorvall RC-5B; Du Pont, Newtown, Conn.). The dry pellet of nucleic acid was resuspended in $10 \mathrm{mM}$ Tris-HCl-1 mM EDTA. The DNA samples were then treated with RNase (Sigma) at a final concentration of $0.1 \mu \mathrm{g} / \mu \mathrm{l}$ at $37^{\circ} \mathrm{C}$ for $20 \mathrm{~min}$. DNA content was determined spectrophotometrically at $260 \mathrm{~nm}\left(A_{260}\right)$. Total DNA $(10 \mu \mathrm{g})$ was loaded on a $1 \%$ agarose gel followed by transfer to a nitrocellulose filter which was prehybridized in a prehybridization buffer $(5 \times$ SSC $[1 \times$ SSC is 0.15 $\mathrm{M} \mathrm{NaCl}$ plus $0.015 \mathrm{M}$ sodium citrate], $0.1 \%$ SDS, $5 \times$ Denhardt's solution, 100 $\mu \mathrm{g}$ of denatured salmon sperm DNA $/ \mathrm{ml}, 50 \%$ formamide) at $68^{\circ} \mathrm{C}$ for $4 \mathrm{~h}$. Hybridization was done for $24 \mathrm{~h}$ at $42^{\circ} \mathrm{C}$ with agitation in the prehybridization buffer plus $5 \times 10^{7} \mathrm{cpm}$ of deoxycytidine $5^{\prime}-\left[\alpha{ }^{32} \mathrm{P}\right]$ triphosphate-labeled HSV- $1 t k$ DNA. The nitrocellulose filter was rinsed three times with $0.1 \times$ SSC (containing $0.1 \% \mathrm{SDS}$ ) at $22^{\circ} \mathrm{C}$ (room temperature) and twice at $65^{\circ} \mathrm{C}$. The filter was then exposed to X-ray film (Kodak).
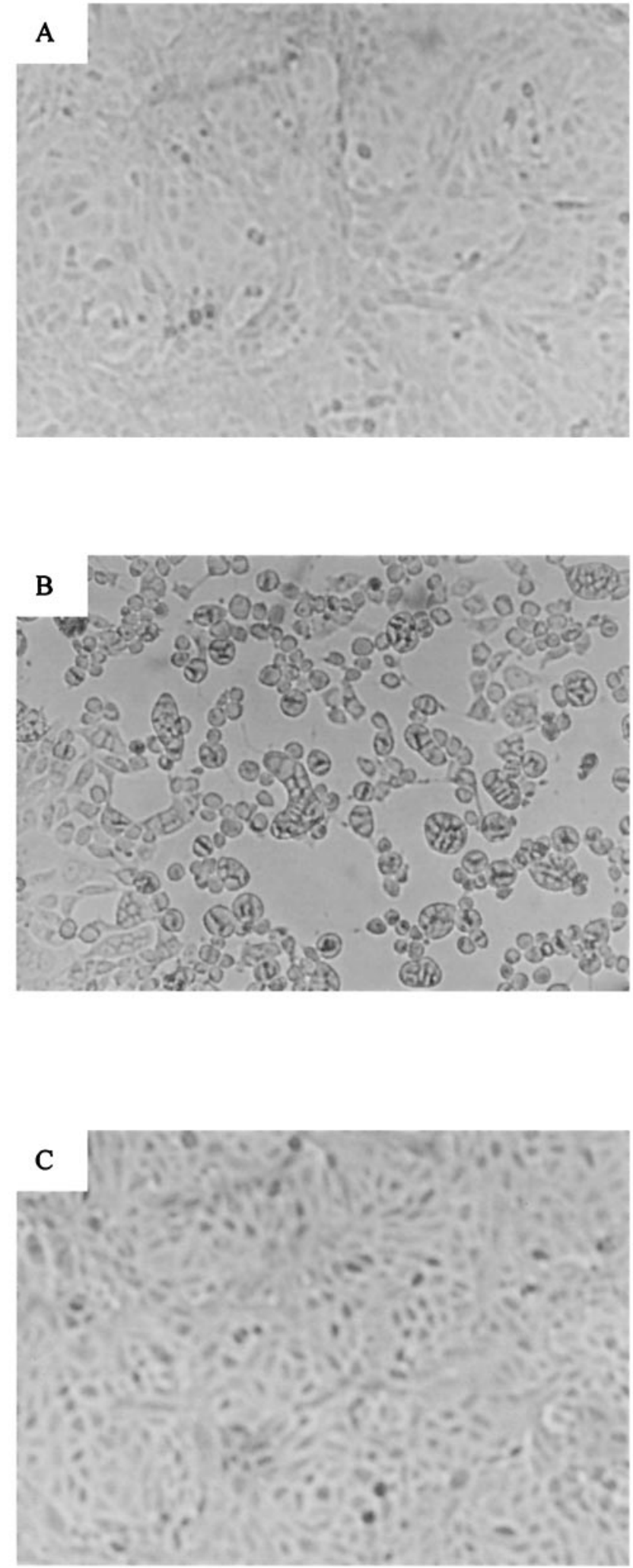

FIG. 1. Inhibition of HSV-1-induced CPE in Vero cells. (A) Untreated Vero cells; (B) CPE in HSV-1-infected $(24 \mathrm{~h})$ Vero cells; (C) HSV-1-infected Vero cells treated with GA $(1 \mu \mathrm{M}, 24 \mathrm{~h})$. 


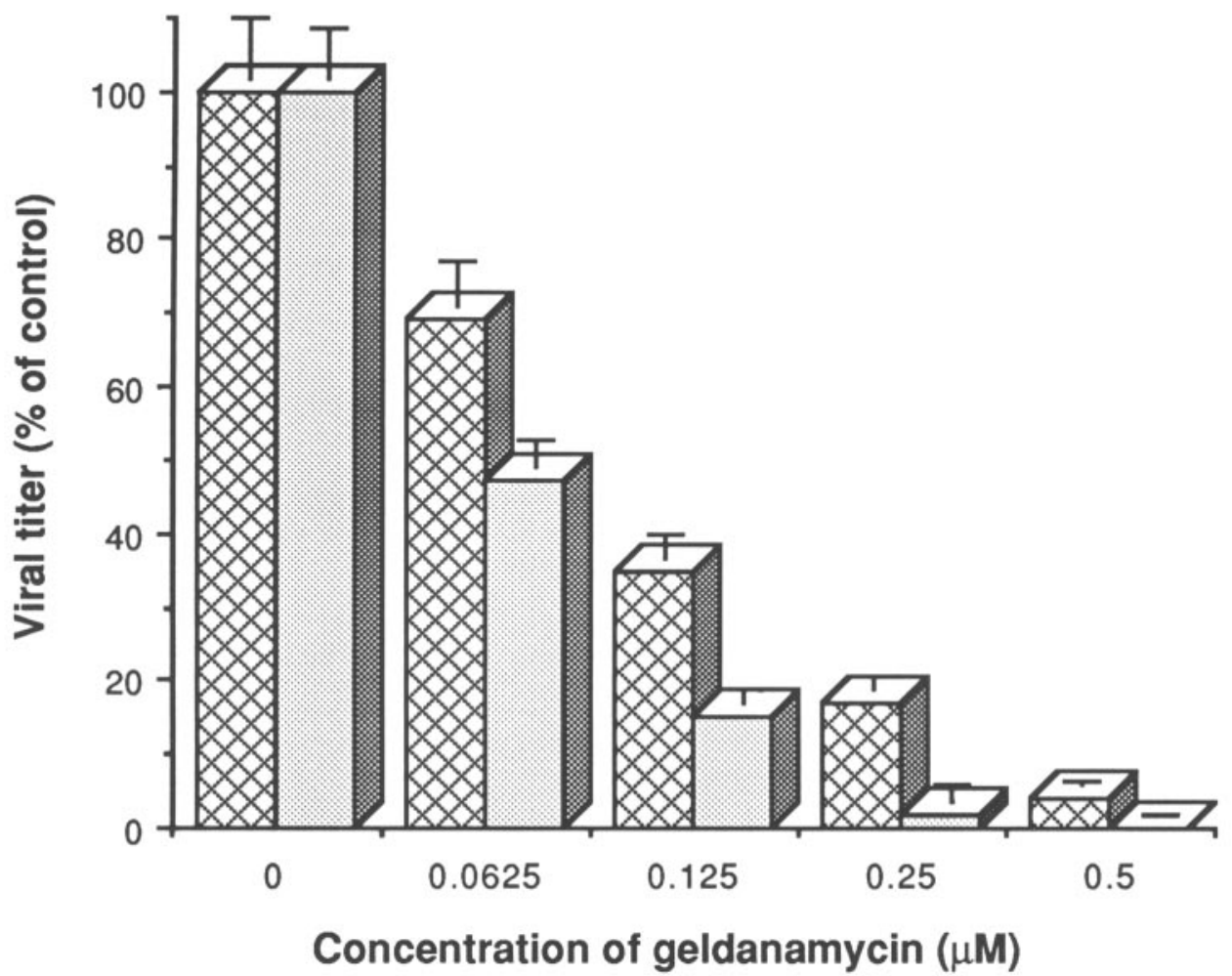

FIG. 2. Reduced release of HSV-1 in Vero cells treated with GA. HSV-1-infected Vero cells were incubated in the absence or presence of GA for $24 \mathrm{~h}$. Intracellular (cross-hatched bars) and supernatant (stippled bars) viral titers were determined separately by plaque assays. Each value represents the mean ( \pm standard deviation $[\mathrm{SD}])$ of the results of triplicate assays.

\section{RESULTS}

Inhibition of HSV-1 replication by GA in vitro. As shown in Fig. 1, GA significantly inhibited HSV-1-induced cytopathic effect (CPE) in Vero cells. Viral titration showed that GA exhibited a dose-dependent inhibition of virus yields (Fig. 2). The $\mathrm{IC}_{50}$ of $\mathrm{GA}$ was $0.093 \mu \mathrm{M}$, and the inhibition rate increased to over $90 \%$ when the GA concentration was increased to $0.5 \mu \mathrm{M}$. The cytotoxic effect of GA on Vero cells was measured with a conventional MTT method, and the $\mathrm{CC}_{50}$ was $350 \mu \mathrm{M}$. The therapeutic index of GA for HSV-1 infection in Vero cells was 3,763 (comparable with that known for the HSV-1 drug acyclovir) (Table 1).

Effects of GA on HSV-1 TK activity, viral adsorption, penetration, and release. To understand the antiviral mechanism of GA, the direct effect of the presence of GA on HSV-1 TK was measured in a cell-free system; the results showed no difference in TK activity levels in the presence or absence of GA $(P>0.05)$. GA treatment did not change viral adsorption and penetration (data not shown). With respect to the reduction of the intracellular viral titer caused by the presence GA, however, release of HSV-1 into the medium by the host cells decreased to a greater degree (Fig. 2), indicating an intracellular obstruction of viral replication.

Restoration by GA of the cell cycle in HSV-1-infected Vero cells. It has been documented that HSV-1 infection caused an arrest of cell cycle at the $G_{1} / S$ transition in host cells, indicating a disruption in regulation of cell cycle $(5,16,37)$. To explore the effect of GA in Vero cells infected with HSV-1, cell cycle analysis was done with naive cells, GA-treated cells, and HSV1 -infected cells as well as with GA-treated HSV $-1^{+}$cells. As shown in Fig. 3, Vero cells treated with GA $(1 \mu \mathrm{M})$ for $24 \mathrm{~h}$ (Fig. 3B) showed a cell cycle profile identical to that of naive Vero cells (Fig. 3A); Vero cells $24 \mathrm{~h}$ after infection of HSV-1 displayed a significant accumulation of the cells at the $G_{1} / S$ transition (Fig. 3C); however, treatment of the HSV $-1^{+}$Vero cells with GA (at $1 \mu \mathrm{M}$ for $24 \mathrm{~h}$ ) resulted in a cell cycle pattern (Fig. 3D) identical to that seen with the naive Vero cells. Similar results were found with HSV-1-infected HeLa cells (Fig. 3E, F, G, and H).

Inhibition of HSV-1 DNA replication by GA in Vero cells. Furthermore, HSV-1 DNA replication was examined to learn whether rescuing the cell cycle from HSV-1 infection by GA would suppress the viral DNA synthesis in host cells. Using a Southern blot technique with HSV-1 tk sequence as a probe, we found that compared to the results seen with the untreated HSV-1-infected Vero cells, GA $(1 \mu \mathrm{M})$ substantially reduced

TABLE 1. Comparison of the anti-HSV-1 activity characteristics of GA and acyclovir in vitro ${ }^{a}$

\begin{tabular}{lrcc}
\hline \multicolumn{1}{c}{ Drug } & $\mathrm{CC}_{50}(\mu \mathrm{M})^{b}$ & \multicolumn{1}{c}{$\mathrm{IC}_{50}(\mu \mathrm{M})^{b}$} & $\mathrm{CC}_{50} / \mathrm{IC}_{50}$ \\
\hline GA & $350 \pm 12$ & $0.093 \pm 0.011$ & 3,763 \\
Acyclovir & $4,400 \pm 84$ & $0.848 \pm 0.015$ & 5,189 \\
\hline
\end{tabular}

${ }^{a}$ Vero cells were infected with HSV-1 followed by treatment with GA or acyclovir; antiviral effect was evaluated by plaque assay (see Materials and Methods).

${ }^{b}$ Means $( \pm$ SDs) were derived from three independent replicates. 

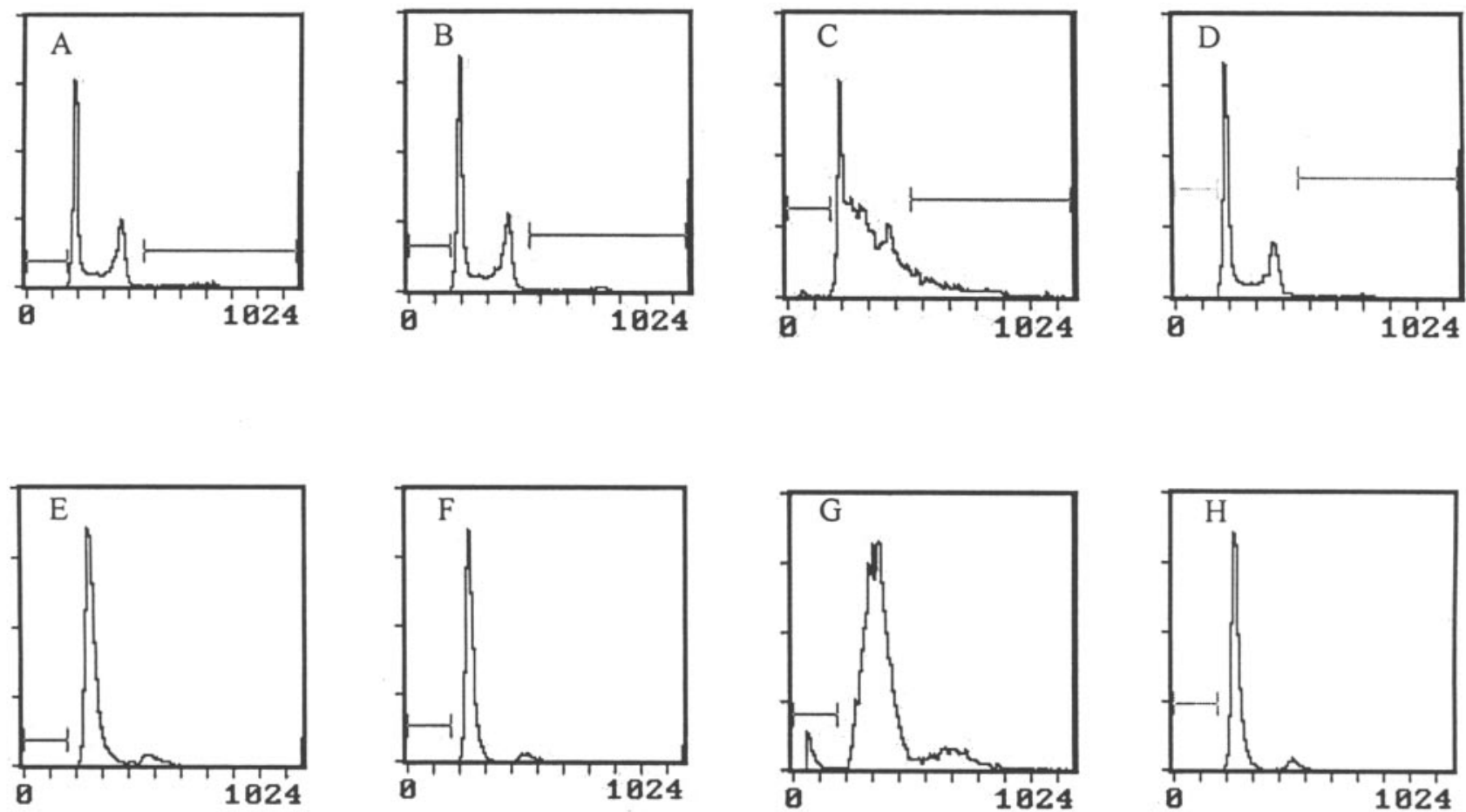

FIG. 3. Restoration of the progression of cell cycle by the presence of GA in Vero cells infected with HSV-1. (A) Untreated Vero cells; (B) GA-treated $(1 \mu \mathrm{M}, 24 \mathrm{~h})$ Vero cells; (C) HSV-1-infected $(24 \mathrm{~h})$ Vero cells; (D) HSV-1-infected Vero cells treated with GA (1 $\mu$ M, 24 h); (E) untreated HeLa cells; (F) GA-treated (1 $\mu$ M, 24 h) HeLa cells; (G) HSV-1-infected (24 h) HeLa cells; (H) HSV-1-infected HeLa cells treated with GA $(1 \mu \mathrm{M}, 24 \mathrm{~h}) . x$ axis, intensity of DNA luminescence; $y$ axis, cell count.

the number of HSV-1 $t k$ copies in $\mathrm{HSV}-1^{+}$cells, indicating an inhibition of the viral DNA synthesis in these cells (Fig. 4). Inhibitory effect was detectable $12 \mathrm{~h}$ after exposure of the HSV$1^{+}$cells to GA and was sustained for more than $24 \mathrm{~h}$ (Fig. 4).
Broad-spectrum antiviral activity of GA. It was our hypothesis that GA should have activities against other viruses if it acts through the inactivation of Hsp90 and restoration of the progression of cell cycle. GA was then tested in vitro for ac-

1 2

3 4
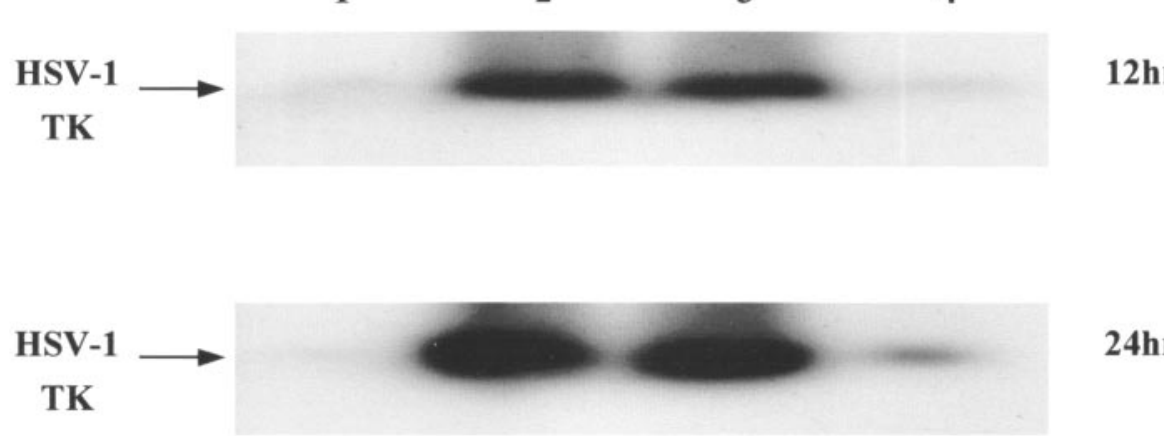

$24 \mathrm{hr}$

GAPDH

$12 \mathrm{hr}$

FIG. 4. GA-induced reduction of HSV-1 DNA synthesis in Vero cells. Vero cells infected with HSV-1 were treated with GA (1 $\mu$ M) for $12 \mathrm{~h}$ or $24 \mathrm{~h}$. Synthesis of HSV-1 DNA $(t k)$ was analyzed by Southern blotting. GAPDH served as an internal control. The 24-h GAPDH control displayed a result similar to that seen at $12 \mathrm{~h}$ and is therefore not shown in this figure to avoid redundancy. Lane 1, normal Vero cells; lane 2, Vero cells infected with HSV-1; lane 3, HSV-1-infected Vero cells treated with solvent dimethyl sulfoxide; lane 4, HSV-1-infected Vero cells treated with GA at $1 \mu \mathrm{M}$. 
TABLE 2. Antiviral activities of GA in vitro

\begin{tabular}{|c|c|}
\hline Virus & $\mathrm{IC}_{50}(\mu \mathrm{M})^{a}$ \\
\hline HSV-2. & $4.0 \pm 1.84$ \\
\hline VSV. & $.1 .52 \pm 1.68$ \\
\hline Cox B3.. & $.3 .35 \pm 2.77$ \\
\hline HIV-1. & $0.5 \pm 0.1$ \\
\hline SARS coronavirus..... & $.0 .91 \pm 0.31$ \\
\hline Influenza virus type $A$ & $\mathrm{NA}^{b}$ \\
\hline Influenza virus type $\mathrm{B}$ & NA \\
\hline
\end{tabular}

${ }^{a}$ Means ( \pm SDs) were derived from at least three independent experiments ${ }^{b}$ NA, not active.

tivity against HSV-2, VZV (vesicular stomatitis virus), Cox B3, HIV-1, and SARS coronavirus as well as for activity against influenza virus types $\mathrm{A}$ and $\mathrm{B}$. As shown in Table 2, GA exhibited broad-spectrum activity against viruses (except influenza virus types $\mathrm{A}$ and $\mathrm{B}$ ). The $\mathrm{IC}_{50}$ ranged between 0.5 and 4 $\mu \mathrm{M}$. HIV-1 and SARS coronavirus exhibited the highest sensitivity to GA in this panel.

\section{DISCUSSION}

Antiviral activity of GA against HSV-1 infection was demonstrated in vitro. The inhibitory effect of GA on HSV-1 was seen to occur in a dose-dependent fashion. Since GA was cytotoxic in tumor cell lines $(13,18)$, one of our major concerns was its toxicity. In the present study, we found that GA had a low toxicity to Vero cells and exhibited a therapeutic index $\left(\mathrm{CC}_{50} / \mathrm{IC}_{50}\right)$ comparable with acyclovir. Since GA inhibited neither HSV-1 TK activity nor viral adsorption or penetration, it provoked our curiosity regarding its antiviral mechanism. Considering that GA is a natural ligand for molecular chaperone Hsp90 that accumulates during HSV-1 infection (15), it was our assumption that a cellular operation related to HSV-1 replication might be the target of GA.

One of the important functions of Hsp90 is to protect its client proteins, such as $\mathrm{p} 53, \mathrm{pRb}$, cyclins and cyclin-dependent kinases, from their degradation $(6,22,39,42)$. These proteins contribute to viral replication in the infected cells in at least two ways. First, some of these client proteins (such as p53, $\mathrm{pRb}$, and cyclin $\mathrm{D}$ ) could be used to induce a cell cycle arrest $(1,5,8,21,38,42)$; second, others (such as CDK2, CDK4, cyclin $\mathrm{T} 1$, and Cdk9) are required for viral replication and could be employed when they are needed $(24,33,34)$. In addition, Hsp90 binds with viral components. Hsp90 had direct interaction with the reverse transcriptase of human hepatitis $\mathrm{B}$ virus (HBV), duck $\mathrm{HBV}$, or avian $\mathrm{HBV}$ in the formation of a ribonucleoprotein complex, which was required early in replication for viral assembly and initiation of DNA synthesis through a protein-priming mechanism $(9,10)$. The role of Hsp90 in viral proliferation in studies of vaccinia virus (11), HIV-1 (24), and hepatitis C virus (40) has also been reported.

To obtain productive viral replication, theoretically, the intruder virus needs a strategy for the creation of a cellular environment that is optimally conductive to its replication (20). Taking over the cell proliferation machinery and suspending the cell cycle at the $\mathrm{G}_{1} / \mathrm{S}$ or $\mathrm{G}_{2} / \mathrm{M}$ phases are parts of the strategy. We did find a cell cycle arrest at the $G_{1} / S$ transition in HSV-1-infected cells. This phenomenon was consistent with observations from studies of other viruses $(17,20,30)$. We also found that HSV-1-disturbed cell cycles could be rescued by GA treatment. We assumed that through inactivation of Hsp90, GA enhanced the degradation of the client proteins and therefore abolished the operation of the cell cycle checkpoint established by HSV-1. The cell cycle was then restored to a normal proliferative phase. This change was in favor of the growth of host cells but not of that of the intruder virus. Of course, one could argue that if what we mentioned above were true, HSV-1 replication should be suppressed by GA; using Southern blotting, we did find a significant reduction of the synthesis of HSV-1 DNA in the GA-treated cells. One could also argue that if this was true, GA should exhibit activity against other viruses. Indeed, we found GA to be active against HSV-2, VSV, Cox B3, HIV-1, and SARS coronavirus. As a matter of fact, the results indicating that GA interrupted the assembly of the Hsp90-dependent Cdk9/cyclin T1 heterodimer (which was required for HIV-1 transcription) (24) are consistent with our finding in this study. Data on the inhibitory effect of GA on SARS coronavirus (Chinese patent application 03146591, July 2003) will be published separately.

The exact antiviral mechanism of GA is still a matter of discussion. Since GA also has an inhibitory effect on cellular DNA polymerase alpha (41) (which is in the same class of DNA polymerases as HSV-1 polymerase), direct inhibition of HSV-1 DNA synthesis could be part of the explanation. The point we have made in this study agrees with the suggestion that cell cycle regulators (such as cyclin-dependent protein kinases) are targets for antiviral drugs $(17,34,35)$. It could be a new mechanism for antiviral agents different from those inhibiting HSV-1 DNA polymerase activity (for example, acyclovir). Hsp90, which plays a key role as a cellular protein in this mechanism, is a novel molecular target for antiviral research. As a matter of fact, our data obtained with radicicol, another known Hsp90 inhibitor (37), were supportive of this point since it also inhibited HSV-1 replication in vitro at an $\mathrm{IC}_{50}$ of $0.1 \mu \mathrm{M}$ (data not shown). Viral inhibition through the regulation of cellular machinery could be a new antiviral approach with the consequential benefits of avoiding induction of resistant viral strains and having a broad-spectrum antiviral activity. In cases of the emergence of a new virus, such as SARS coronavirus, agents in this category are of particular value because they might inhibit the replication of the new virus before the viral target proteins are characterized.

Taken together, these data indicate that since GA (an antibiotic extracted by fermentation) has a significant inhibitory effect against HSV-1 in vitro and restrains HSV-1 replication through a cellular mechanism unique among HSV-1 drugs, there is justification for development of this antibiotic as a new agent for HSV-1 infection.

\section{ACKNOWLEDGMENTS}

The project was supported by the National Natural Science Foundation of the People's Republic of China (grants 398708889 and 39930190)

We deeply thank L. M. Schang (Department of Microbiology, University of Pennsylvania School of Medicine, Philadelphia, Penn.) for the generous gifts of the plasmids prpTK and pTRI-GAPDH.

\section{REFERENCES}

1. Asher, G., J. Lotem, R. Kama, L. Sachs, and Y. Shaul. 2002. NQO1 stabilizes p53 through a distinct pathway. Proc. Natl. Acad. Sci. USA 99:3099-3104. 
2. Blagosklonny, M. V. 2002. Hsp-90-associated oncoproteins: multiple targets for geldanamycin and its analogs. Leukemia 16:455-462.

3. DeBoer, C., P. A. Meulman, R. J. Wnuk, and D. H. Peterson. 1970. Geldanamycin, a new antibiotic. J. Antibiot. (Tokyo) 23:442-447.

4. DeSalle, L. M., and M. Pagano. 2001. Regulation of the $G_{1}$ to $S$ transition by ubiquitin pathway. FEBS Lett. 490:179-189.

5. Ehmann, G. L., T. I. McLean, and S. L. Bachenheimer. 2000. Herpes simplex virus type 1 infection imposes a $G_{1} / S$ block in asynchronously growing cells and prevents $G_{1}$ entry in quiescent cells. Virology 267:335-349.

6. Helmbrecht, K., E. Zeise, and L. Rensing. 2000. Chaperones in cell cycle regulation and mitogenic signal transduction: a review. Cell Prolif. 33:341365 .

7. Highlander, S. L., W. H. Cai, S. Person, M. Levine, and J. C. Glorioso. 1987. Neutralizing monoclonal antibodies specific for herpes simplex virus glycoprotein D inhibit virus penetration. J. Virol. 61:3356-3364.

8. Hossain, A., T. Holt, J. Ciacci-Zanella, and C. Jones. 1997. Analysis of cyclin-dependent kinase activity after herpes simplex virus type 2 infection. J. Gen. Virol. 78:3341-3348.

9. Hu, J., and C. Seeger. 1996 . Hsp90 is required for the activity of a hepatitis B virus reverse transcriptase. Proc. Natl. Acad. Sci. USA 93(3):1060-1064.

10. Hu, J., D. O. Toft, and C. Seeger. 1997 . Hepadnavirus assembly and reverse transcription require a multi-component chaperone complex which is incorporated into nucleocapsids. EMBO J. 16:59-68.

11. Hung, J. J., C. S. Chung, and W. Chang. 2002. Molecular chaperone Hsp90 is important for vaccinia virus growth in cells. J. Virol. 76:1379-1390.

12. Jiang, J. D., Y. Wang, J. Roboz, J. Strauchen, J. F. Holland, and J. G. Bekesi. 1998. Inhibition of microtubule assembly in tumor cells by 3-bromoacetylamino benzoylurea, a new cancericidal compound. Cancer Res. 58: 2126-2133.

13. Kim, S., J. Kang, W. Hu, B. M. Evers, and D. H. Chung. 2003. Geldanamycin decreases Raf-1 and Akt levels and induces apoptosis in neuroblastomas. Int J. Cancer 103:352-359.

14. Larsson, A., and P. Z. Tao. 1984. Phosphorylation of four acyclic guanosine analogs by herpes simplex virus type 2 thymidine kinase. Antimicrob. Agents Chemother. 25:524-526.

15. La Thangue, N. B., and D. S. Latchman. 1988. Acellular protein related to heat-shock protein 90 accumulates during herpes simplex virus infection and is overexpressed in transformed cells. Exp. Cell Res. 178:169-179.

16. Lomonte, P., and R. D. Everett. 1999. Herpes simplex virus type 1 immediate-early protein Vmw110 inhibits progression of cells through mitosis and from $G_{1}$ into $S$ phase of the cell cycle. J. Virol. 73:9456-9467.

17. Luo, H., J. Zhang, F. Dastvan, B Yanagawa, M. A. Reidy, H. M. Zhang, D. Yang, J. E. Wilson, and B. M. McManus. 2003. Ubiquitin-dependent proteolysis of cyclin D1 is associated with coxsackievirus-induced cell growth arrest. J. Virol. 77:1-9.

18. Mabjeesh, N. J., D. E. Post, M. T. Willard, B. Kaur, E. G. Van Meir, J. W. Simons, and H. Zhong. 2002. Geldanamycin induces degradation of hypoxiainducible factor 1 alpha protein via the proteosome pathway in prostate cancer cells. Cancer Res. 62:2478-2482.

19. Maki, C. G., J. M. Huibregtse, and P. M. Howley. 1996. In vivo ubiquitination and proteasome-mediated degradation of p53. Cancer Res. 56:26492654.

20. Marechal, V., and T. Piolot. 2000. Lytic infection by double-strand DNA viruses and cell cycle alterations. Pathol. Biol. (Paris) 48:289-300.

21. Morita, E., K. Tada, H. Chisaka, H. Asao, H. Sato, N. Yaegashi, and K. Sugamura. 2001. Human parvovirus B19 induces cell cycle arrest at $\mathrm{G}_{2}$ phase with accumulation of mitotic cyclins. J. Virol. 75:7555-7563.

22. Nakai, A., and T. Ishikawa. 2001. Cell cycle transition under stress conditions controlled by vertebrate heat shock factors. EMBO J. 20:2885-2895.

23. Ochel, H. J., K. Eichhorn, and G. Gademann. 2001. Geldanamycin: the prototype of a class of antitumor drugs targeting the heat shock protein 90 family of molecular chaperones. Cell Stress Chaperones 6:105-112.
24. O'Keefe, B., Y. Fong, D. Chen, S. Zhou, and Q. Zhou. 2000. Requirement for a kinase-specific chaperone pathway in the production of a Cdk9/cyclin T1 heterodimer responsible for P-TEFb-mediated tat stimulation of HIV-1 transcription. J Biol. Chem. 275:279-287.

25. Pearl, L. H., and C. Prodromou. 2000. Structure and in vivo function of Hsp90. Curr. Opin. Struct. Biol. 10:46-51.

26. Piper, P. W. 2001. The Hsp90 chaperone as a promising drug target. Curr. Opin. Investig. Drugs 2:1606-1610.

27. Prodromou, C., S. M. Roe, R. O'Brien., J. E. Ladbury, P. W. Piper, and L. H. Pearl. 1997. Identification and structural characterization of the ATP/ADPbinding site in the Hsp90 molecular chaperone. Cell 90:65-75.

28. Richter, K., and J. Buckner. 2001. Hsp90: chaperoning signal transduction. J. Cell Physiol. 188:281-290.

29. Roe, S. M., C. Prodromou, R. O'Brien, J. E. Ladbury, P. W. Piper, and L. H. Pearl. 1999. Structural basis for inhibition of the Hsp90 molecular chaperone by the antitumor antibiotics radicicol and geldanamycin. J. Med. Chem. 42:260-266.

30. Roshal, M., B. Kim, Y. Zhu, P. Nghiem, and V. Planelles. 2003. Activation of the ATR-mediated DNA damage response by the HIV-1 viral protein R. J. Biol. Chem. 278:25879-25886.

31. Rubinstein, L. V., R. H. Shoemaker, K. D. Paull, R. M. Simon, S. Tonisi, P. Skehan, D. A. Scudiero, A. Monks, and M. R. Boyd. 1990. Comparison of in vitro anticancer-drug-screening data generated with a tetrazolium assay versus a protein assay against a diverse panel of human tumor cell lines. J. Natl. Cancer Inst. 82:1113-1118.

32. Sainz, B., Jr., and W. P. Halford. 2002. Alpha/beta interferon and gamma interferon synergize to inhibit the replication of herpes simplex virus type 1 . J. Virol. 76:11541-11550.

33. Schang, L. M., A. Bantly, and P. A. Schaffer. 2002. Explant-induced reactivation of herpes simplex virus occurs in neurons expressing nuclear cdk 2 and cdk4. J. Virol. 76:7724-7735.

34. Schang, L. M., A. Bantly, M. Knockaert, F. Shaheen, L. Meijer, M. H. Malim, N. S. Gray, and P. A. Schaffer. 2002. Pharmacological cyclin-dependent kinase inhibitors inhibit replication of wild-type and drug-resistan strains of herpes simplex virus and HIV-1 by targeting cellular, not viral, proteins. J. Virol. 76:7874-7882

35. Schang, L. M. 2002. Cyclin-dependent kinases as cellular targets for antiviral drugs. J. Antimicrob. Chemother. 50:779-792.

36. Sullivan, W., B. Stensgard, G. Caucutt, B. Bartha, N. McMahon, E. S. Alnemri, G. Litwack, and D. Toft. 1997. Nucleotides and two functional states of hsp90. J. Biol. Chem. 272:8007-8012.

37. Vanden, B. T., M. Kalai, G. van Loo, W. Declerecq, and P. Vandenabeele. 2003. Disruption of Hsp90 function reverts tumor necrosis factor-induced necrosis to apoptosis. J. Biol. Chem. 278:5622-5629.

38. Van Sant, C., Y. Kawaguchi, and B. Roizman. 1999. A single amino acid substitution in the cyclin D binding domain of the infected cell protein no. 0 abrogates the neuroinvasiveness of herpes simplex virus without affecting its ability to replicate. Proc. Natl. Acad. Sci. USA 96:8184-8189.

39. Wang, H., T. Goode, P. Iakova, J. H. Albrecht, and N. A. Timchenko. 2002. $\mathrm{C} / \mathrm{EBP}$ alpha triggers proteosome-dependent degradation of cdk4 during growth arrest. EMBO J. 21:930-941.

40. Waxman, L., M. Whitney, B. A. Pollok, L. C. Kuo, and P. L. Darke. 2001. Host cell factor requirement for hepatitis $\mathrm{C}$ virus enzyme maturation. Proc. Natl. Acad. Sci. USA 98:13931-13935.

41. Yamaki, H., H. Suzuki, E. C. Choi, and N. Tanaka. 1982. Inhibition of DNA synthesis in murine tumor cells by geldanamycin, an antibiotic of the benzoquinoid ansamycin group. J. Antibiot. (Tokyo) 35:886-892.

42. Zhao, C., A. Hashiguchi, K. Kondoh, W. Du, J. Hata, and T. Yamada. 2002. Exogenous expression of the heat shock protein $90 \mathrm{kDa}$ retards the cell cycle and impairs the heat shock response. Exp. Cell Res. 275:200-214. 